\section{References}

Anderson, D. C. (1970). Clinica Chimica Acta, 29, 513.

Collins, W. P. (1972). Scandinavian fournal of Clinical and Laboratory

Investigation. In press.
Hall, R., Ormston, B. J., Besser, G. M., Cryer, R. J., and McKendrick, M. (1972). Lancet, 1,759 .

McCann, S. M., and Dhariwal, A. P. S. (1964). Transactions of the New York Academy of Sciences, 27, 39

McCann, S. M., and Dhariwal, A. P. S. (1966). In Neuroendocrinology, ed. L. Martini, and W. F. Ganong, p. 276. London, Academic Press.
Matsuo, H., Baba, Y., Nair, R. M. G., Arimura, A., and Schally, A. V. (1971). Biochemical and Biophysical Research Communications, 43, 1334. Ormston, B. J., Garry, R., Cryer, R. J., Besser, G. M., and Hall, R. (1972). Lancet, $2,10$.

Schally, A. V., Baba, Y., Arimura, A., Redding, T. W., and White, W. F. (1971a). Biochemical and Biophysical Research Communications, 42, 50 Schally, A. V., et al. (1971b). Biochemical and Biophysical Research Communications, 43, 393.

Schally, A. V., et al. (1971c). Science, 173, 1036.

\title{
Effect of Synthetic Luteinizing Hormone Releasing Hormone (LH/FSH-RH) in Women with Menstrual Disorders
}

\author{
JOHN NEWTON, WILLIAM P. COLLINS
}

British Medical fournal, 1972, 3, 271-273

\section{Summary}

Synthetic luteinizing hormone/follicle stimulating hormone-releasing hormone (LH/FSH-RH) (50 $\mu \mathrm{g})$ was given intravenously to six women with oligomenorrhoea and to four women with secondary amenorrhoea. Peripheral venous blood was withdrawn at regular intervals over a 24-hour period. The concentrations of $\mathrm{LH}$, FSH, and oestradiol-17 $\beta$ were determined by radioimmunoassay. In all subjects there was a variable rise in $\mathbf{L H}$ (3-16 times the mean basal level): in six a small rise in FSH (two to three times the mean basal level) and in seven a twofold to threefold rise in oestradiol three to eight hours after the rise in gonadotrophins.

\section{Introduction}

There is good evidence to believe that the release of luteinizing hormone $(\mathrm{LH})$ and follicle stimulating hormone (FSH) is under a neuroendocrine control emanating from the hypothalamus (Guillemin and Schally, 1963). Evidence for a specific LHreleasing hormone (LH-RH) in rat hypothalamic extracts was first presented by McCann et al. (1960) and in sheep by Courrier et al. (1961).

Recently Schally et al. (1971) showed that a purified extract of pig hypothalami (LH-RH) has both $\mathrm{LH}$ and $\mathrm{FSH}$ releasing properties in rats. Human subjects given this purified porcine LH-RH also release LH and FSH (Kastin et al., 1971), as do monkeys, sheep, and rabbits (Reeves et al., 1970; Schally et al., 1970). Kastin et al. (1970) also isolated two fractions from human hypothalami with LH-RH and FSH-RH activity, and when given separately both produced a significant increase in FSH and LH after administration to volunteers.

Schally et al. (1971) proposed a provisional structure for porcine LH-RH, which was revised and found to be a decapeptide (Matsuo et al., 1971). A product with this amino-acid sequence has now been manufactured by Hoechst Pharmaceuticals and was used in the present study.

\footnotetext{
Department of Obstetrics and Gynaecology, King's College Hospital, London S.E.5

\section{Patients and Methods}

Patients selected for this study were all volunteers. They were admitted to hospital on the day before the test and were kept in bed for the duration of the study but were not fasting. A No. 16-gauge angiocath was inserted into an antecubital fossa vein and connected to an extension tube and three-way tap. The tube and angiocath were flushed with heparinized sterile distilled water between each sample. Blood was withdrawn to determine basal hormone levels at 8, 8.30, and 8.50 a.m. A 50- $\mu \mathrm{g}$ dose of synthetic LH-RH (HOE 471) was dissolved in $0.9 \%$ sterile saline solution and diluted to $10 \mathrm{ml}$ in the same material. This was injected via the intravenous line at 9 a.m. Blood samples were then withdrawn at the following times after the injection: $5,10,15,20$, and 30 minutes; and $1,1 \frac{1}{2}, 2,3,6,9$, and 24 hours. The blood samples were centrifuged immediately, the plasma being separated and deep frozen at $-25^{\circ} \mathrm{C}$ until assayed. FSH and LH were determined by radioimmunoassay using a pituitary standard LER 907 (Wide and Porath, 1966) and oestradiol-17 $\beta$ by radioimmunoassay using an anti-serum to oestradiol-6carboxymethyl oxime-bovine serum albumin (Emment et al., 1972).

The first six patients had oligomenorrhoea with cycles of six to eight weeks. These patients do not have the premenstrual rise in LH and FSH (Newton, 1972c; Ross et al., 1970) which occurs in the normal menstrual cycle (Newton et al., 1971a); the injection of LH-RH was given on the first day of bleeding. The last four patients had secondary amenorrhoea for not less than six months and had previously been investigated to assess their basal endocrine state (Newton 1972a, 1972b).

\section{Results}

The data in Tables I and II show the first significant rise of LH and FSH after the injection of synthetic LH-RH, the time at which the peak level was reached, the duration of raised gonadotrophin levels, and the factorial increase of LH and FSH over the mean basal sample (mean of three). As can be seen from Table $I$ there was a rise in $\mathrm{LH}$ in all 10 patients. Three showed the first significant rise 5 minutes after the injection, five after 10 minutes, and two after 15 minutes. The peak value for $\mathrm{LH}$ was reached after 30 minutes in four patients, 45 in two patients, and 90 minutes in two patients. The duration of response varied from 45 minutes to 8 hours 50 minutes, with five patients between 2 hours 50 minutes and 2 hours 55 minutes. The 
TABLB I-Change in Plasma LH after LH-RH

\begin{tabular}{c|c|c|c|c}
\hline Case No. & $\begin{array}{c}\text { Time of First } \\
\text { Significant } \\
\text { Rise in LH } \\
\text { (Min) }\end{array}$ & $\begin{array}{c}\text { Time of } \\
\text { Peak Value } \\
\text { (Min) }\end{array}$ & $\begin{array}{c}\text { Duration of } \\
\text { Raised Levels } \\
\text { (Hr min) }\end{array}$ & $\begin{array}{c}\text { Factorial } \\
\text { Increase }\end{array}$ \\
\hline 1 & 10 & 30 & 850 & $\times 7 \cdot 6$ \\
2 & 10 & 90 & 250 & $\times 8 \cdot 9$ \\
3 & 5 & 60 & 255 & $\times 7 \cdot 3$ \\
4 & 15 & 30 & 045 & $\times$ \\
5 & 15 & 45 & 145 & $\times 16 \cdot 3$ \\
6 & 5 & 60 & 255 & $\times 6 \cdot 0$ \\
7 & 10 & 90 & 250 & $\times 8 \cdot 3$ \\
8 & 10 & 30 & 120 & $\times 7 \cdot 2$ \\
9 & 10 & 45 & 150 & $\times 9 \cdot 4$ \\
10 & 5 & 30 & 255 & $\times 14.8$ \\
\hline
\end{tabular}

TABLB II-Change in Plasma FSH after LH-RH

\begin{tabular}{|c|c|c|c|c|}
\hline Case No. & $\begin{array}{c}\text { Time of First } \\
\text { Significant Rise } \\
\text { (Min) }\end{array}$ & $\begin{array}{c}\text { Time of Peak } \\
\text { Value } \\
\text { (Min) }\end{array}$ & $\begin{array}{l}\text { Duration of } \\
\text { Raised Levels } \\
\text { (Hr Min) }\end{array}$ & $\begin{array}{l}\text { Factorial } \\
\text { Increase }\end{array}$ \\
\hline $\begin{array}{r}1 \\
2 \\
3 \\
4 \\
5 \\
6 \\
7 \\
8 \\
9 \\
10\end{array}$ & $\begin{array}{c}10 \\
15 \\
15 \\
\text { No change } \\
\text { No change } \\
\text { No change } \\
\text { No change } \\
15 \\
10 \\
10\end{array}$ & $\begin{array}{r}180 \\
15 \\
30 \\
= \\
= \\
= \\
30 \\
60 \\
60\end{array}$ & $\begin{array}{l}250 \\
245 \\
= \\
= \\
\overline{1} \\
250\end{array}$ & $\begin{array}{r}\times 2.9 \\
\times 2.2 \\
\times 2.3 \\
= \\
= \\
\times 2.0 \\
\times 2.0 \\
\times 2.4\end{array}$ \\
\hline
\end{tabular}

factorial increase over the basal level ranged from 3.5 to $16 \cdot 3$, with a mean value of $8 \cdot 9$.

In Table II it may be seen that the FSH results are more variable; only six of the 10 patients showed an increase. In three of these the first rise was detectable 10 minutes after the injection and in the remaining three after 15 minutes. The peak value was seen at 15 minutes in one patient, 30 minutes in two patients, and 3 hours in one patient. In two patients there was no sustained rise of $\mathrm{FSH}$, but in four the duration of response varied from 1 hour 20 minutes to a maximum of 2 hours 50 minutes. The factorial increase in FSH was lower than with $\mathrm{LH}$, varying from 2.0 to 2.9 , with a mean of 2.3 . The basal and peak values for LH, FSH, and oestradiol are given in Table III.

TABLE III-LH, FSH, and Oestradiol Levels

\begin{tabular}{c|c|c|c|c|c|c}
\hline Case No. & \multicolumn{2}{|c|}{ LH (mIU/ml) } & \multicolumn{2}{c|}{ FSH (mIU/ml) } & \multicolumn{2}{c}{ Oestradiol (pg/ml) } \\
\hline & Basal Value & Peak Value & Basal Value & Peak Value & Basal Value & Peak Value \\
\hline 1 & 7.27 & 55 & 5.2 & 15 & 32 & 98 \\
2 & 8.99 & 80 & 14.8 & 32.5 & 41 & 78 \\
3 & 22 & 160 & 10.7 & 24.5 & 38 & 108 \\
4 & 22.86 & 80 & 12.8 & No change & 97 & 291 \\
5 & 6.75 & 110 & 19.8 & No change & 55 & 79 \\
6 & 6.25 & 37.5 & 8.6 & No change & 45 & 99 \\
7 & 7.4 & 61.2 & 9.8 & No change & $\frac{-}{7}$ & $=$ \\
8 & 6.0 & 43.2 & 11.3 & 22.5 & $=$ & $=$ \\
9 & 19.15 & 183 & 9.8 & 20.5 & $\overline{5}$ & 95 \\
10 & 7.2 & 106 & 11.5 & 27.6 & 50 & \\
\hline
\end{tabular}

The values for $\mathrm{LH}, \mathrm{FSH}$, and oestradiol obtained from a patient given $50 \mu \mathrm{g} \mathrm{LH}-\mathrm{RH}$ are charted in Fig. 1. There was a rapid initial rise in $\mathrm{LH}$ which reached a plateau after 30 minutes and then gradually fell from a level of $55 \mathrm{mIU} / \mathrm{ml}$ to near basal levels nine hours later. Next morning there was a rise in $\mathrm{LH}$, and 8 days and 24 days later the values were similar to those seen before the test. The FSH increase was much smaller; a plateau was reached after 15 minutes and showed very little change over the next nine hours. The results 8 days and 24 days later were also very similar to the pretreatment values. The level of plasma oestradiol tended to fall for the first 90 minutes, then increased, reaching a maximum at 6 hours. The concentration then fell over the next 18 hours to preinjection values. The level on day 8 was similar. On day 24 there was a rise to $99 \mathrm{pg} / \mathrm{ml}$, which is within the normal luteal phase range. This patient showed a basal temperature shift 14 days after the injection of LH-RH but there was no conclusive proof of ovulation and she did not menstruate 28 days after the injection.
Fig. 2 shows the same results for $\mathrm{LH}$ and FSH plotted on a logarithmic scale. The release of $\mathrm{LH}$ was linear for the first $15 \mathrm{~min}$ utes after injection, the slope then changed, and for the next 6 hours the release was more gradual, but the levels did not return to pretreatment values. FSH showed a more variable response,

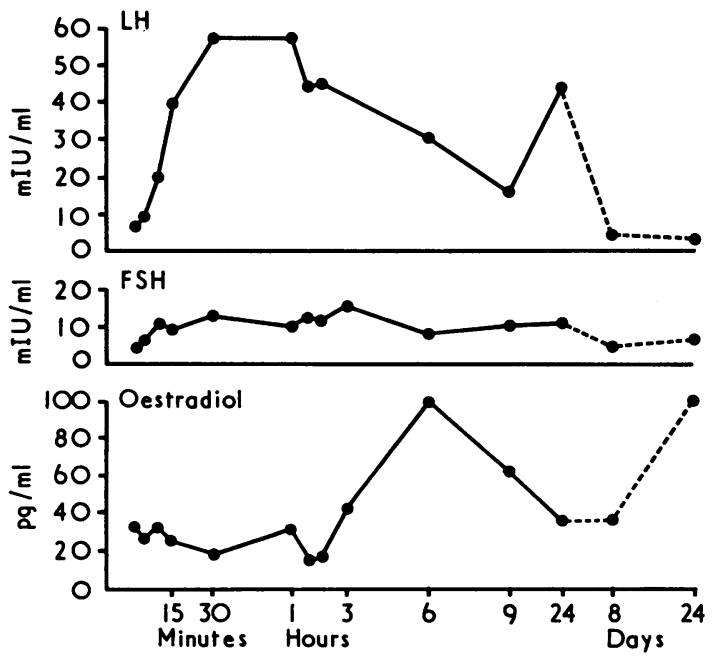

FIG. 1-LH-RH, Case 1. Hormone changes after $50 \mu \mathrm{g}$ LH-RH.

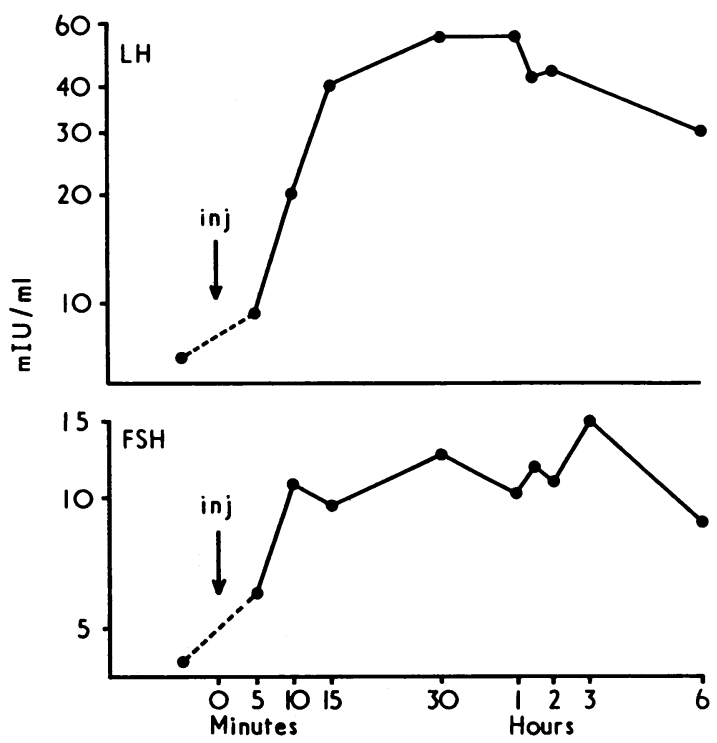

FIG. 2-LH-RH, Case 1. Log plot of LH and FSH against time.

the levels fluctuating throughout the period of test but remaining above the preinjection level of $6 \mathrm{mIU} / \mathrm{ml}$. This type of response, shown in Figs. 1 and 2, was seen in most cases; however, in two patients a biphasic release was observed. One of these is illustrated in Fig. 3. Initially there was a rapid rise in $\mathrm{LH}$, reaching a peak after 10 minutes. Levels then fell, and a second peak occurred $1 \frac{1}{2}$ hours after the injection; the levels again fell over the next $5 \frac{1}{2}$ hours. The FSH rose, reaching a peak after 15 minutes, then decreased over the next 60 minutes and remained fairly constant for the rest of the test. The concentration of oestradiol started to increase 2 hours after the injection, reached a maximum value after 3 hours, and remained elevated for a period of 6 hours. 


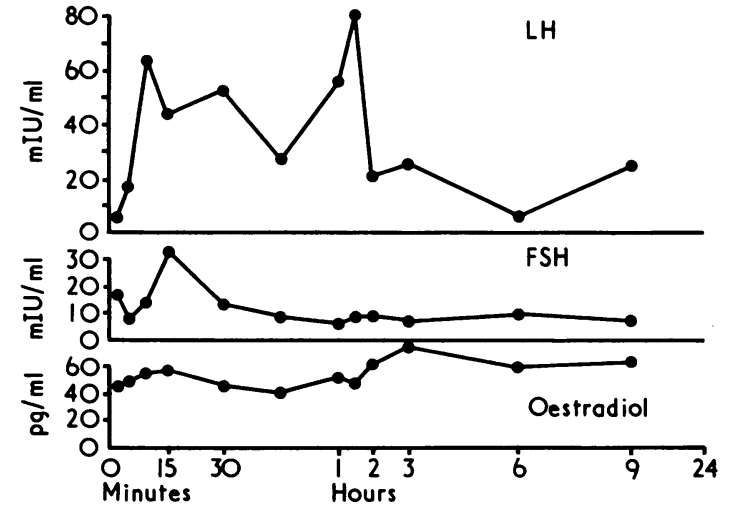

FIG. 3-LH-RH, Case 2. Hormone changes after $50 \mu g$ LH-RH showing biphasic pattern.

\section{Discussion}

The presence of LH-RH in the hypothalami of animals such as rats and pigs (Schally et al., 1968) and of man (Schally et al., 1967) has been described. Attempts have been made to purify this substance, which in pigs was found to have the following sequence of amino-acids (pyro) : Glu-His-Trp-Ser-Tyr-GlyLeu-Arg-Pro-Gly-NH $\mathrm{NH}_{2}$ (Matsuo et al., 1971). This decapeptide has been synthesized (Arimura et al., 1972) and its biological activity found to be similar to natural LH-RH.

In this preliminary series of patients all showed an increase in LH after injection of $50 \mu \mathrm{LH} / \mathrm{FSH}-\mathrm{RH}$, but only six showed an increase in FSH and only four showed a sustained increase in FSH. In all these patients the FSH increase was lower (mean 2.3) than for LH (mean 8.9). The radioimmunoassays for $\mathrm{LH}$ and FSH are specific, and this therefore seems to indicate that the main action of LH/FSH-RH in these patients is to release $\mathrm{LH}$, and in some a smaller rise in FSH can also be expected. Further work in progress will help to elucidate whether LH/FSH-RH releases both FSH and LH or whether LH-RH and FSH-RH are in fact two different compounds. Oligomenorrhoeic patients were chosen for this initial study to avoid the natural increase in endogenous LH and FSH seen premenstrually and for the first few days of the menstrual cycle in normal patients with regular menstrual cycles.

There is a need for a pituitary function test that measures directly the release of LH and FSH. Previous work with clomiphene (Newton and Dixon, 1971) has indicated that it acts on the hypothalamic-pituitary axis and that it is useful as a test of pituitary function (Newton et al., 1971b). Hopefully, LH/FSHRH will be capable of development as a test of pituitary function in patients suspected of having a disorder of the pituitary, and when used in combination with clomiphene will enable disorders of the hypothalamic-pituitary axis to be better understood. In addition ovulation induction, which has been carried out in golden hamsters with LH/FSH-RH (Arimura et al., 1972), may be possible in patients and provide a useful form of treatment.

We would like to thank Dr. J. Sandow, Dr. K. Bruch, and Dr. R. Rousell for the supply of synthetic LH/FSH-RH; and the M.R.C. for their support (grant No. G971/7773c). The National Institute for Health donated materials used in the radioimmunoassay of gonadotrophins, and Professor H. Lindner supplied the antiserum to oestradiol-17 $\beta$.

\section{References}

Arimura, A., et al. (1972), Endocrinology, 90, 163.

Courrier, R., Guillemin, R., Jutisz, M., Sakiz, E., Pand Aschheim, P. (1961). Comptes Rendus Hebdomadaires des Séances de l'Académie des Sciences, 253, 922.

Emment, Y., Collins, W. P., and Sommerville, I. F. (1972). Acta Endocrinologica, 69, 567.

Guillemin, R., and Schally, A. V. (1963). In Advances in Neuroendocrinology, ed. A. V. Nalbandov, p. 314. Urbana, U.S.A., University of Illinois Press.

Kastin, A. J., et al. (1970). American fournal of Obstetrics and Gynaecology, $108,177$.

Kastin, A. J., et al. (1971). Fournal of Clinical Endocrinology and Metabolism, $32,287$.

McCann, S. M., Talivsnik, S., and Friedman, H. M. (1960). Proceedings of the Society for Experimental Biology and Medicine, 104, 432.

Matsuo, H., Baba, Y., Nair, R. M. G., Arimura, A., and Schally, A. V. (1971). Biochemical and Biophysical Research Communications, 43, 1334.

Newton, J. R. (1972a). British fournal of Hospital Medicine, 7, 564

Newton, J. R. (1972b). Fournal of Obstetrics and Gynaecology of the British Commonwealth. In press.

Commonwealth. In press.
Newton, J. R. (1972c). Postgraduate Medical fournal, 48, 5.

Newton, J. R., and Dixon, P. F. (1971). Fournal of Obstetrics and Gynaecology of the British Commonwealth, 78, 812.

Newton, J. R., Joyce, D., Peirce, R. B., Tyler, J., and Revell, C. (1971a). fournal of Reproduction and Fertility, 27, 481.

Newton, J. R., Ramsay, I., and Marsden, P. (1971 ib). Lancet, 2, 190.

Reeves, J. J., Arimura, A., and Schally, A. V. (1970). Fournal of Animal Science, 31, 933.

Ross, G. T., et al. (1970). Recent Progress in Hormone Research, 26, 1.

Schally, A. V., et al. (1967). Fournal of Clinical Endocrinology and Metabolism, 27, 755 .

Schally, A. V., et al. (1968). Recent Progress in Hormone Research, 24, 497.

Schally, A. V., et al. (1970). In Mammalian Reproduction, ed. H. Vivian and E. J. Plotz, p. 45. Berlin, Springer.

Schally, A. et al. (1971). Biochemical and Biophysical Research Communications, 43, 243.

Wide, L., and Porath, J. (1966). Biochimica et Biophysica Acta, 130, 257. 